\title{
PENGATURAN KOMPETENSI KOMISARIS INDEPENDEN DALAM MEWUJUDKAN GOOD CORPORATE GOVERNANCE
}

\author{
Oleh: \\ Ni Komang Putri Rahayu'
}

\begin{abstract}
The objective of the research is to reveal the Competence of Independent Commissioners in realizing Good Corporate Governance. The research method used is normative juridical research method with a conceptual approach, legislation, and case approach. The result of the research shows that the Independent Competence of Independent Commissioners in achieving Good Corporate Governance means that the regulation of the competence and integrity requirements of independent commissioners in Good Corporate Governance, especially the competency requirements are regulated in Limited Liability Company Law and Capital Market Law which regulates core business competence and core competency behavior. Meanwhile, the integrity of an independent commissioner is regulated in a code of conduct that an independent commissioner must adhere to.
\end{abstract}

Keywords: Independent Commissioner, Corporate Governance, Competence, Integrity.

\begin{abstract}
Abstrak
Tujuan penelitian untuk mengetahui pengaturan Kompetensi Komisaris Independen dalam mewujudkan Good Corporate Governance. Metode penelitian yang digunakan adalah metode penelitian yuridis normatif dengan pendekatan-pendekatan konseptual, perundang-undangan dan pendekatan kasus. Hasil penelitian menunjukkan pengaturan Kompetensi Komisaris Independen dalam mewujudkan Good Corporate Governance dimaksudkan bahwa pengaturan syarat kompetensi dan integritas komisaris independen dalam Good Corporate Governance khususnya syarat kompetensi diatur dalam UndangUndang Perseroan Terbatas dan Undang-Undang Pasar Modal yang mengatur mengenai kompetensi inti bisnis dan kompetensi inti perilaku. Sementara itu, untuk integritas komisaris independen diatur dalam code of conduct (pedoman perilaku) yang harus dipatuhi oleh komisaris independen.
\end{abstract}

\section{Kata Kunci: Komisaris Independen, Tata Kelola Perusahaan, Kompetensi,} Integritas. Program Studi Magister (S2) Ilmu Hukum Universitas Udayana, Denpasar, Bali, e-mail:
putrirahayu319@yahoo.com 


\section{PENDAHULUAN}

Good Corporate Governance yang merupakan suatu hal yang menjadi keharusan di Indonesia, mengingat buruknya persepsi dunia luar terhadap Indonesia dan tingginya ekspektasi terhadap perusahaan publik dan BUMN untuk menjadi tulang punggung perekonomian Indonesia Namun demikian hal ini seharusnya tidak dianggap sebagai penghalang, namun dapat dijadikan pemacu untuk memotivasi seluruh organ perusahaan dalam mengusung semangat Good Corporate Governance.

Dalam perusahaan Dewan Komisaris memegang peranan yang sangat penting, terutama dalam pelaksanaan Good Corporate Governance. Menurut Egon Zehnder, ${ }^{2}$ Dewan Komisaris merupakan inti dari CorporateGovernanceyangditegaskan untuk menjadikan pelaksanaan strategi perusahaan, mengawasi manajemen dalam mengelola perusahaan, serta mewajibkan terlaksananya akuntabilitas dan bertanggungjawab untuk mengawasi manajemen, dengan demikian DewanKomisaris merupakan suatu pusat ketahanan dan kesuksesan perusahaan.

Salah satu upaya yang dapat ditempuh dalam mewujudkan Good Corporate Governance dalam pengelolaan korporasi adalah dengan membentuk Komisaris Independen yang duduk dalam ajaran pengurus perseroan, terutama pada perusahaan

2 Egon Zehnder International, Corporate Governance and the Role of the Board of Directors. 2000, hlm. 35. publik (public listing company). Komisaris independen adalah komisaris yang bukan merupakan anggota manajemen, pemegang saham mayoritas, pejabat maupun seseorang yang berhubungan secara langsung ataupun tidak langsung dengan pemegang saham mayoritas dari suatu perusahaan yang mengawasi pengelolaan perusahaan. $^{3}$ Komisaris Independen tidak boleh terlepas dari perspektif prinsip GCG secara keseluruhan di suatu perusahaan dimana independency, transparency, accountability, responsibility, dan fairness yang menjadi landasan utama dalam menjalankan perusahaan.

Penelitian tentang pengaturan pada kompetensi komisaris independen dalam mewujudkan Good Corporate Governance dari segi substansinya, penelitian yang paling dekat dengan materi pengaturan kompetensi komisaris independen dalam mewujudkan Good Corporate Governance adalah (1) Firmansyah melakukan penelitian pada tahun 2010 dengan judul "Peranan Mengoptimalkan Fungsi Auditor Internal dalam Penerapan GCG di PT BNI. tbk", yang dimuat dalam Jurnal Ilmu Hukum Syair Hukum, Volume XII, Nomor 1; (2) Badriyah Rifai, melakukan penelitian pada tahun 2010 dengan judul "Peran Komisaris Independen dalam mewujudkan GCG

3 Indra Surya dan Ivan Yustiavandana, Penerapan Good Corporate Governance Mengesampingkan Hak-hak Istimewa demi Kelangsungan Usaha, Kencana, Jakarta, 2006, hlm. 135. 
di Perusahaan Publik", yang dimuat dalam Jurnal Hukum, Volume 16, Nomor 3; dan (3) Djohari Santosa melakukan penelitian pada tahun 2008 dengan judul "Kegagalan Penerapan GCG Pada Perusahaan Publik di Indonesia", yang dimuat dalam Jurnal Hukum, Nomor 2, Volume 15. Dari perbedaan penelitian-penelitian tersebut, penelitian ini memberikan kontribusi untuk menjadi bahan pemikiran maupun masukan dalam hal peranan komisaris independen dalam mewujudkan Good Corporate Governance di Indonesia.

Adapun tujuan penelitian ini adalah untuk mengetahui pengaturan kompetensi komisaris independen dalam mewujudkan Good Corporate Governance di Indonesia.

\section{METODE PENELITIAN}

Sejalan dengan permasalahan penelitian ini, maka metode penelitian hukum yang digunakan bersifat penelitian hukum yuridis normatif dengan pendekatan konsep (conceptual approach), pendekatan perundangundangan (statuta approach) dan pendekatan kasus (case approach). Teknik pengambilan bahan hukum dilakukan melalui studi kepustakaan. Teknik analisis bahan hukum yang digunakan merupakan analisis yuridis. Objek atau sasaran yang merupakan data penelitian ini pada dasarnya berkisar pada kajian ilmu hukum, yang bertitik berat pada substansi atau regulasi hukum mengenai pengaturan kompetensi komisaris independen dalam mewujudkan Good Corporate Governance.

\section{HASIL DAN PEMBAHASAN}

Saat ini memang sangat banyak seorang yang menjalankan bisnis dengan berbagai macam dan ragam jenis korporasi mulai menjalankan tata kelola, hal ini sangat terdorong pada kebutuhan pasar yang menuntut perusahaan public yang menjalankan sistem manajemen secara baik. Pedoman umum Good Corporate Governance di Indonesia disusun oleh Komite Nasional Kebijakan Governance. Metode penerapan Pedoman Good Corporate Governance oleh perusahaan-perusahaan di Indonesia baik perusahaan terbuka maupun perusahaan tertutup pada dasarnya bersifat comply and explain. Aspek Pedoman Good Corporate Governancediharapkanditerapkanoleh perusahaan-perusahaan di Indonesia. ${ }^{4}$ Apabila belum seluruh aspek pedoman ini dilaksanakan maka perusahaan harus mengungkapkan aspek yang belum dilaksanakan tersebut beserta alasannya dalam laporan tahunan. Namun demikian mengingat pedoman ini hanya merupakan acuan sedangkan pelaksanaannya diharapkan diatur lebih lanjut oleh otoritas masingmasing industri, maka penerapan ini bersifat voluntary dan tidak terdapat sanksi hukum apabila perusahaan tidak menerapkan pedoman ini.

4 Komite Nasional Kebijakan Governance (KNKG), op.cit, hlm.ii. 
Dewan Komisaris dalam melaksanakan tugas pengawasannya dapat membentuk komite yang akan membantu tugas-tugas dewan komisaris. Bagi perusahaan yang sahamnya tercatat di bursa efek, perusahaan negara, perusahaan daerah, perusahaan yang menghimpun dan mengelola dana masyarakat, perusahaan yang produk atau jasanya digunakan oleh masyarakat luas, serta perusahaan yang mempunyai dampak luas terhadap kelestarian lingkungan, sekurang-kurangnya harus membentuk Komite Audit, sedangkan komite lain dibentuk sesuai dengan kebutuhan.

Namun sayangnya UUPT justru belum mengatur mengenai kompetensi dari komisaris independen (norma kosong). UUPT hanya mengatur mengenai jumlah komisaris independen dan pengangkatan komisaris independen saja, yang diatur hanya dalam 1 (satu) pasal yaitu Pasal 120 UUPT. Pasal 120 ayat (1) UUPT mengatur perseroan untuk mempunyai sekurang kurangnya satu orang komisaris independen. Sementara itu Pasal 120 ayat (2) UUPT menegaskan bahwa komisaris independen diangkat berdasarkankeputusanRUPSdaripihak yang tidak terafiliasi dengan pemegang saham utama, anggota direksi dan/atau anggota dewan komisaris lainnya. Selain 2 (dua) ketentuan tersebut UUPT tidak mengatur hal lainnya mengenai komisaris independen termasuk kompetensinya juga belum diatur dalam UUPT. Komisaris independen lebih banyak ditentukan oleh peraturan yang tumbuh dan berkembang dalam praktik hukum seperti misalnya KNKCG tadi.

Di dunia usaha sekarang ini, dalam pelaksanaan prinsip GCG sangat memerlukan Komisaris Independen yang perkembangan bisnisnya ini sangat patut mendapatkan pujian, dikarenakan memperlihatkan adanya kegiatan usaha secara baik. Apabila tidak berfungsinya komisaris independen maka diperkirakan membuka suatu peluang perusahaan melakukan kecurangan. Padahal kehadiran komisaris independen sangat penting bagi terciptanya penyelenggaraan perusahaan dengan baik. $^{5}$

Dalam Perseroan Terbatas Komisaris Independen memiliki tanggung jawab yang sangat besar. Dapat dicontohkan sebagai berikut, pada jaman Orde Baru, pensiunan Jendral masih banyak yang diangkat sebagai komisaris, meskipun mereka jarang ke kantor, bahkan mereka tidak mengetahui atau memahami asal usul serta permasalahan perseroan, yang mereka dudukan sebagai komisaris. Dalam suatu perseroan, harus diwajibkan mempunyai sekurangkurangnya satu orang komisaris yang independen dan satu orang komisaris utusan (Pasal 120 ayat (1) UndangUndang Nomor 40 Tahun 2007 tentang Perseroan Terbatas.

5 Sinar Harapan.co.id, 10 Oktober 2004, diakses 8 Juni 2017 
Dalam pasar modal, keberadaan Komisaris Independen memegang suatu peranan penting, diharapkan mereka dapat membawa suara para pemegang saham minoritas dalam sebuah perusahaan yang Go Public. Oleh sebab itu orang yang memiliki integritas, kredibilitas dan profesional dapat menjadi Komisaris Independen. Selain itu jangan sampai mereka mau disogok demi kepentingan pemegang saham mayoritas. ${ }^{6}$

Good Corporate Governance diperlukan untuk mendorong terciptanya pasar yang efisien, transparan dan konsisten dengan peraturan perundang-undangan. Oleh karena itu penerapan Good Corporate Governance perlu didukung oleh tiga pilar yang saling berhubungan, yaitu negara dan perangkatnya sebagai regulator, dunia usaha sebagai pelaku pasar, dan masyarakat sebagai pengguna produk dan jasa dunia usaha. Prinsip-prinsip Good Corporate Governance mengacu kepada pendapat Cadbury Committee ${ }^{7}$ secara umum ada lima prinsip dasar dari GCG, yaitu: Transparency, Accountability, Responsibility, Independency, dan Fairness, yang untuk memudahkan dapat diakronimkan menjadi tarif.

Peranan Komisaris Independen dan Komite Audit mengupayakan peningkatan dalam Menciptakan Good

6 Sinar Harapan.co.id, 24 Oktober 2004, diakses 8 Juni 2017

7 Cadbury Report., The Report of the Cadbury Commite on Financial Aspect of Corporate Governance: The Code of Best Practise, Cadbury-Schweppes, 2006, hlm. 8.
Corporate Governance di Indonesia. Saat ini Good Corporate Governance sudah menjadi suatu kebutuhan bagi suatu negara atau perusahaan yang ingin masuk ke dalam kegiatan bisnis internasional. Seorang investor akan membeli saham dengan harga yang tinggi, salah satu indikatornya adalah apakah perusahaan (emiten) menerapkan prinsip Good Corporate Governance secara baik atau tidak. Dengan demikian, prinsip Good Corporate Governance telah menjadi suatu prinsip yang sangat penting bagi keberhasilan pengelolaan perusahaan.

Salah satu upaya yang dapat ditempuh dalam mewujudkan Good Corporate Governance dalam pengelolaan korporasi adalah dengan membentuk Komisaris Independen dan Komite Audit yang duduk dalam jajaran pengurus perseroan, terutama pada perusahaan publik (public listing company). Mengungkapkan peningkatan peranan Komisaris Independen dan Komite Audit dalam kaitannya untuk menciptakan Good Corporate Governance di Indonesia di masa mendatang, sama halnya membicarakan peran Komisaris Independen dan Komite Audit yang mendekati ideal.

Komisaris Independen idealnya merupakan komisaris yang bukan merupakan anggota manajemen, pemegang saham mayoritas, pejabat ataupun seseorang yang berhubungan secara langsung ataupun tidak langsung dengan pemegang saham 
mayoritas dari suatu perusahaan yang mengawasi pengelolaan perusahaan. Di masa depan dalam suatu perseroan, diwajibkan mempunyai sekurang kurangnya satu orang Komisaris Independen, yang berasal dari luar perusahaan serta tidak mempunyai hubungan bisnis dengan perusahaan atau afiliasinya. Komisaris Independen ini diharapkan dapat menciptakan keseimbangan berbagai kepentingan pihak, seperti pemegang saham utama, direksi, komisaris, manajemen, karyawan, maupun pemegang saham publik.

Keberadaan

Komisaris

Independen dan Komite Audit sangat penting dalam menciptakan GCG di Indonesia. Kedudukan kedua organ ini dalam perusahaan publik adalah berkaitan dengan tanggung jawab pengawasandaridewankomisaris. Oleh sebab itu, keberadaan dari Komisaris Independen yang duduk dalam Komite Audit dan Anggota Komite Audit, wajib untuk menaati ketentuan tentang kegiatan dari Komite Audit. Sebagai komite yang membantu fungsi pengawasan komisaris, Komite Audit memiliki fungsi dalam hal yang terkait dengan proses dan peran audit bagi perusahaan, terutama dalam pelaporan hasil audit keuangan perusahaan yang dipaparkan untuk publik.

\section{KESIMPULAN}

Pengaturan

Kompetensi

Komisaris Independen dalamkaitannya untuk mewujudkan Good Corporate
Governance bahwa Untuk pengaturan syarat kompetensi belum diatur dalam Undang-Undang Perseroan Terbatas (UUPT) dan Undang-Undang Pasar Modal (UUPM) yang mengatur mengenai kompetensi inti bisnis dan kompetensi inti perilaku. Sementara itu untuk integritas Komisaris Independen code of conduct (pedoman perilaku) yang harus dipatuhi oleh Komisaris Independen. Pertemuan antara kompetensi dan integritas akan membentuk kompetensi pribadi Komisaris Independenyangmerupakan kompetensi seorang Komisaris Independen untuk mengintegrasikan pengetahuan, keterampilan, sikap dan nilai-nilai pribadi berdasarkan pengalaman dan pembelajaran dalam pelaksanaan tugas Komisaris Independen secara profesional, efektif dan efisien.

\section{DAFTAR PUSTAKA}

\section{BUKU}

Cadbury, A. (1992). Report of the committee on the financial aspects of corporate governance (Vol. 1). Gee. Egon Zehnder International, Corporate Governance and the Board of Directors. 2000.।

Kebijakan, K. N. Governance (KNKG). 2006. Pedoman Umum Good Corporate Governance Indonesia. Jakarta.

Surya, I., Yustiavandana, I., \& Nefi, A. (2006). Penerapan 
good corporate governance:

mengesampingkan hak-hak

istimewa demi kelangsungan

usaha. Kencana.

\section{ARTIKEL JURNAL}

Firmansyah,

"Peranan

Mengoptimalkan Fungsi Auditor

Internal dalam Penerapan GCG di PT BNI, tbk", Jurnal Ilmu Hukum Syiar Hukum, Volume XII, Nomor 1, 2010.

Rifai, B. (2016). Peran Komisaris Independen dalam Mewujudkan Good Corporate Governance di Perusahaan Publik. Jurnal Hukum IUS QUIA IUSTUM, 16(3), 396-412.

Santoso, D. (2008). Kegagalan

Penerapan Good Corporate Governance Pada Perusahaan Publik Di Indonesia. Jurnal Hukum IUS QUIA IUSTUM, 15(2).

\section{PERATURAN}

\section{PERUNDANG-UNDANGAN}

Undang-Undang Nomor 8 Tahun 1995 tentang Pasar Modal

Undang-Undang Nomor40 Tahun 2007 tentang Perseroan Terbatas.

\section{SUMBER INTERNET}

Sinar Harapan.co.id, 10 Oktober 2004, diakses 8 Juni 2017

Pedoman Umum Pelaksanaan GCG Indonesia, diakses 8 Juni 2017

Majalah News Letter, 2002, diakses 8 Juni 2017. 